6. Ямашкин А.А. Геоэкологический анализ процесса хозяйственного освоения ландшафтов Мордовии / А. А. Ямашкин. - Саранск : Изд-во Мордов. ун-та, 2001. 232c.

7. Ямашкин А.А., Кирюшин А.В., Коваленко А.К. и др. Геоэкологический анализ состояния природно-социально-производственных систем. Саранск: Изд-во Мордов. ун-та, 2004. 260 с.

\title{
Выбор жидкости при проведении гидравлического разрыва пласта
}

\author{
Кокарев М.О., магистр, \\ E-mail: 13050465@mail.ru \\ Семенович С.П., студент, \\ E-mail: 13050465@mail.ru
}

Южно-Российский государственный политехнический университет

(НПИ) имени М.И. Платова, г. Новочеркасск

Научный руководитель: к.т.н., доцент Рыбальченко Ю.М.

На современном этапе развития разработки нефтяных месторождений так называемой «легкой» нефти практически нет. Все месторождения, которые сейчас разрабатываются, либо на стадии завершающейся, либо это новые месторождения, где нефть извлечь трудно. В наших геологических условиях, когда больше 70 \% нефти находится в трудно извлекаемых пластах, ГРП это единственный способ, применяя который становится возможным экономически рентабельно бурить и вводить в эксплуатацию новые скважины и ремонтировать старые.

ГРП является сложным технологическим процессом, вособенности при его проведении в сложных геологических условиях в горизонтально направленных скважинах. В таких ситуациях важным при проведения гидроразрыва пласта является использование высококачественных материалов для приготовления рабочей жидкости. Технология ГРП предусматривает приготовление жидкости разрыва путем смешивания основной фазы (воды или нефти), расклинивающего агента (естественные пески и искусственные керамические или бокситовые проппанты) и специальных химических добавок (стабилизатор глин, загуститель, реагент для снижения показателя фильтрации и трения и т.д.)[1, 2].

В качестве рабочего реагента при проведении гидроразрыва пласта применяются различные жидкости, обладающие разнообразными физическими параметрами. К данным жидкостям применяются следующие требования [1, 2]:

- рабочие жидкости, нагнетаемые в пласт, не должны уменьшать ни абсолютную, ни фазовую проницаемость породы пласта. Поэтому, при ГРП в нефтяных скважинах могут применяться жидкости как на углеводородной основе, так и на водной основе;

- рабочие жидкости для ГРП не должны содержать посторонних механических примесей и при соприкосновении с пластовыми жидкостями и породой пласта не должны образовывать нерастворимых осадков; 
- рабочие жидкости для ГРПне должны обладать свойствами, обеспечивающими наиболее полное их удаление из созданных трещин и порового пространства пород;

- вязкость рабочих жидкостей должна быть стабильна в условиях обрабатываемого пласта в пределах времени проведения процесса ГРП.

Жидкости гидроразрыва делятся на три категории: жидкость разрыва, жидкость песконоситель, продавочная жидкость. [1, 2]

Вязкость. Вязкость жидкости разрыва в очень большой степени влияет на то, как жидкость поглощается породой пласта: густой жидкости теряется меньше, чем маловязкой. Более вязкие жидкости образуют с проппантом почти идеальную суспензию, что позволяет заполнить проппантом весь объем трещины.

Эффективность. Величина "эффективность жидкости ГРП" показывает, какой объем жидкости поглощается пластом по отношению к количеству жидкости, создающему трещину. Чем ниже потери жидкости, тем выше ее эффективность, т.к. исключается вероятность быстрого смыкания трешины. При этом должна быть обеспечена необходимая концентрация проппанта.

Коэффициент фильтруемости (КФ). КФ применяется для количественной характеристики потерь жидкости, учитывает свойства породы пласта, свойства жидкости и параметры жидкости разрыва.[3]

Для приготовления качественных жидкостей гидроразрыва на водной основе необходимо предварительно проверить воду на наличие железа (Fe), сульфатов $\left(\mathrm{SO}_{4}^{2-}\right)$, гидрокарбонатов $\left(\mathrm{HCO}_{3}^{-}\right)$и др. соединений. Только в этом случае возможно приготовление жидкостей ГРП с физическими параметрами согласно проектным. Кроме того, следует учитывать, что пласты так же насыщены минеральными солями, а в некоторых случаях и газами, которые могут создавать химически активную среду при взаимодействии с жидкостями гидроразрыва. Аномально высокие давление и температура могут выступать не только негативными факторами, влияющими на параметры жидкости ГРП, но и выступать катализаторами реакций. Как правило, используют техническую опресненную воду.

Жидкости гидроразрыва на нефтяной основе имеют некоторые преимущества перед водными: нефть более вязкая, обладает более высокой расклинивающей способностью и менее рассеивается в пласте и, следовательно, требует меньшую производительность насосов. Однако, по сравнению с водными жидкости ГРП на нефтяной основе имеют меньшую плотность, вследствие чего требуется большее давление для гидроразрыва. Так же нефть имеет более низкую температуру застывания.

Гуар является природным полимером. Наиболее часто используем в отечественной практике. Применяется для придания жидкости гидроразрыва гелеобразной структуры.

Главное требование к физико-химическим свойствам гуара - эффективность технологической жидкости на протяжении всей операции ГРП. Достигается это путем сочетания (вначале) высокой вязкости с добавлением химреагентов, снижающими показатель фильтрации, повышенными песконесущими способностями, а также регулируемой в сторону понижения вязкости (по окончании) за счет специальных реагентов - разгелевателей. Для обработки высокотемпературных скважин жидкость гидроразрыва должна быть термостабильной т.е. при термодеструкции она не должна быстро терять свою вязкость. 
Гидроксипропилгуар получается взаимодействием пропиленоксида с гидроксильной группой элементарного звена макромолекулы гуара, что дает более термостабильный и более вязкий гель. К тому же продукты гуара обычно дают негидратирующийся остаток в пределах 8-12\%, а гидроксипропилгуара - 1-4\%. Что позволяет получать трещину с большой проводимостью.

В карбонатных коллекторах используются загущенная соляная кислота.

Загущенный метанол или пены используются в основном на газовых месторождениях или месторождениях с низкой проницаемостью.

Мицелярные растворы применяются в условиях, когда необходимо обеспечить наибольшую проницаемость трещины. [1,7]

Проппант предназначен для предотвращения смыкания трещины после окончания закачивания. Проппант добавляется к жидкости глушения и закачивается вместе с ней.

Возможности трещины транспортировать жидкость к стволу скважины, обусловлены пропускной способностью трещины. Обычно она определяется произведением проницаемости трещины и ширины трещины:

$$
s=k \cdot w
$$

где к - проницаемость (миллидарси); w - ширина трещины (мм).

При производстве ГРП, для того чтобы регулировать процессы оседания, применяют методы закачки проппанта различных фракций (табл. 1). Примером такой технологии можетслужить закачка основного объема песка, или среднепрочного проппанта типа 20/40, с последующей закачкой средне- или высокопрочного проппанта типа 16/20 или 12/20 в количестве $10-40 \%$ от общего объема. При этом достигаются следующие цели:

- крепление трещины высокопрочным проппантом в окрестности скважины, где напряжение сжатия наиболее высокое;

- снижение стоимости операции, так как керамические проппанты в 2 - 4 раза дороже песка;

- создание наибольшей проводимости трещины в окрестности забоя, где скорость фильтрации флюида максимальная;

- предотвращение выноса проппанта в скважину. [4]

Таблица 1

Размер частиц песка, применяемого при ГРП

\begin{tabular}{|c|c|}
\hline Размер сит & Предельные размеры частиц (мм) \\
\hline 100 & 0,150 \\
\hline $40-60$ & $0,419-0,250$ \\
\hline $20-40$ & $0,841-0,419$ \\
\hline $12-20$ & $1,679-0,841$ \\
\hline $8-12$ & $2,380-1,679$ \\
\hline
\end{tabular}

Поскольку проппанты (расклинивающие агенты) должны противостоять напряжениям в горной породе, удерживая трещину раскрытой после снятия гидравлического давления жидкости разрыва, прочность материала имеет особую важность. Расклинивающий материал должен быть достаточно прочным, чтобы выдерживать напряжение смыкания трещины, в противном случае проводимость слоя 
(раздробленного) проппанта будет значительно ниже запроектированного значения (уменьшается как ширина, так и проницаемость слоя проппанта) (рис. 1).

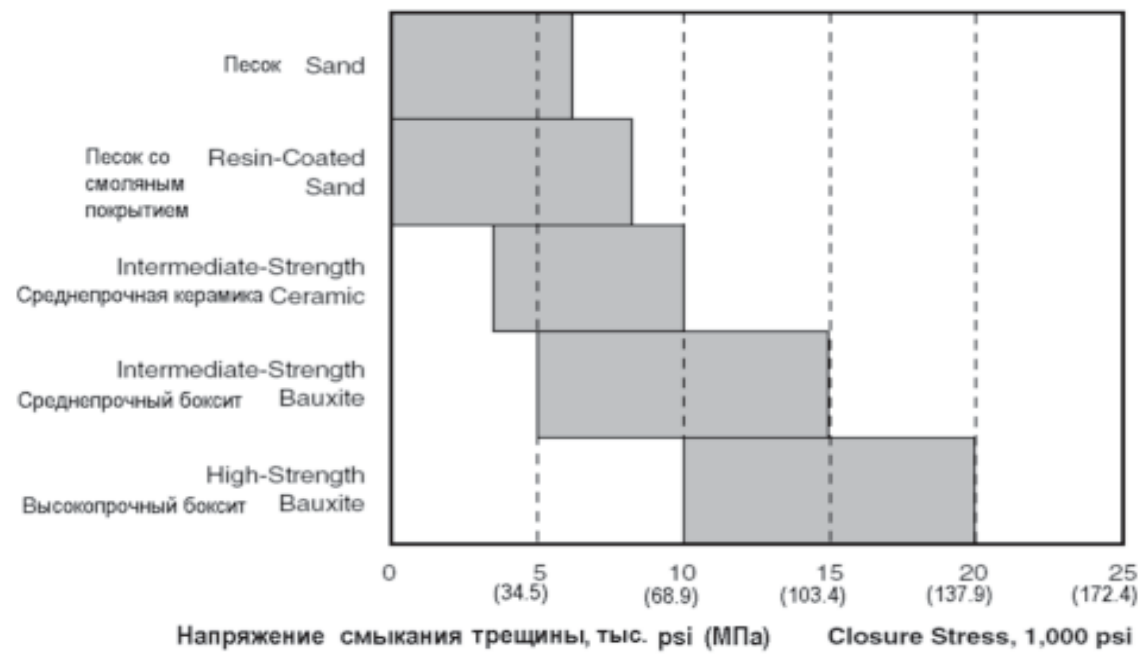

Рис. 1. Принцип выбора проппанта

Существует две основные категории проппантов - это естественные пески и искусственные керамические или бокситовые проппанты. Пески используются для гидроразрыва пластов в условиях низких напряжений, для глубин примерно до 2400 м и меньше (предпочтительно, намного меньше). Искусственные проппантыиспользуются при высоких напряжениях, как правило, в пластах на глубинах свыше 2400 м.[5]

Используются для создания специфического эффекта, не зависящего от типа жидкости (табл.2).

Таблица 2

Добавки к жидкостям гидроразрыва

\begin{tabular}{|c|c|c|}
\hline Добавка & $\begin{array}{c}\text { Концентрация, л или кг на м³ } \\
\text { чистой жидкости }\end{array}$ & Назначение \\
\hline $\begin{array}{c}\text { Биоцид } \\
\text { (бактерицид) }\end{array}$ & $0.1-1.0$ л/м $\mathrm{M}^{3}$ & $\begin{array}{c}\text { Предотвращает } \\
\text { бактериальное разложение } \\
\text { гуарового полимера }\end{array}$ \\
\hline $\begin{array}{c}\text { Тампонирующие } \\
\text { материалы }\end{array}$ & 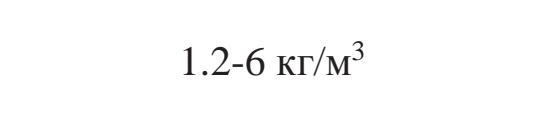 & $\begin{array}{c}\text { Уменьшает утечку жидкости } \\
\text { в пласт при гидроразрыве }\end{array}$ \\
\hline Деструкторы & 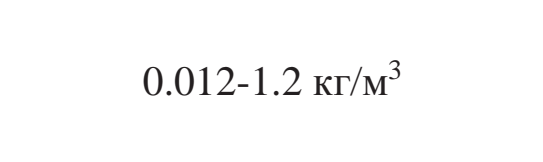 & $\begin{array}{c}\text { Обеспечивают } \\
\text { контролируемое понижение } \\
\text { вязкости жидкости }\end{array}$ \\
\hline $\begin{array}{c}\text { Понизители } \\
\text { трения }\end{array}$ & $0.1-1$ л/м $\mathrm{M}^{3}$ & $\begin{array}{c}\text { Уменьшают потери давления } \\
\text { на трение при закачке }\end{array}$ \\
\hline $\begin{array}{c}\text { Поверхностно-активные } \\
\text { вещества (ПАВ) } \\
\end{array}$ & $0.05-10$ л/ $\mathrm{M}^{3}$ & $\begin{array}{c}\text { Уменьшают поверхностное } \\
\text { натяжение }\end{array}$ \\
\hline Пенообразователи & $1-10 \pi / \mathrm{M}^{3}$ & $\begin{array}{c}\text { Обеспечивают образование } \\
\text { устойчивой пены с азотом } \\
\text { или двуокисью углерода }\end{array}$ \\
\hline
\end{tabular}


Добавки для контура

набухания глин как правило, 1-3 \% KCl
Обеспечивают временную

или постоянную

совместимость глин с водой

Таким образом ГРП - это не просто метод интенсификации и увеличения притока нефти и нефтеотдачи, но и средство разработки месторождений. Известно, что важнейший показатель проектов на разработку месторождений - коэффициент извлечения нефти. Он редко бывает больше 35\%, как правило от 30 до 40 \% или в долях единицы - это 0,3 - 0,4.

Применение ГРП и вовлечение в разработку ранее не дренированных участков пластов позволяет на старых фондах скважин на несколько процентов поднять коэффициент извлечения нефти. Использование этого метода избавляет от необходимости забуривания дополнительных боковых стволов и скважин.

В отечественной практике имеется большой опыт по применению гидроразрыва.К примеру, на старых месторождениях ООО «РН-Юганскнефтегаза» таких как УстьБалыкское и Мамонтова применяя ГРП удалось увеличить текущую добычу, предотвратить падение и реанимировать старый фонд скважин. [6]

Список литературы:

1. Третьяк А.Я., Зиновьев В.В., Чихоткин В.Ф., Рыбальченко Ю.М., Чикин А.В. Методы увеличения нефтеотдачи пластов: Учеб. пособие / Юж.-Рос. гос. техн. ун-т. Новочеркасск: ЮРГТУ (НПИ), 2005. - 227 с.

2. Желтов Ю. П. Разработка нефтяных месторождений: Учебник для вузов - М.: Недра, 1986. 332 с.

3. Ремонт нефтяных и газовых скважин: учебное пособие / И. И. Кагарманов, А. Ю. Дмитриев. - М.: Изд-во ТПУ, 2007.

4. Инструкция по технологии глубокопроникающего гидравлического разрыва пласта. М., 1998. РМНТК - Нефтеотдача.

5. Справочная книга по текущему и капитальному ремонту скважин/ А.Д. Амиров, А.К. Карапетов, Ф.Д. Лемберанский. М.: Недра, 1979.

6. URL: http://neftegaz.ru (дата обращения: 24.02.2016 г.).

7. URL: http://www.neftepro.ru (дата обращения: 24.02.2016 г.)

\section{Разработка нового вида огранки для муассанита}

Корнилов П.В., студент, Северо-Восточный федеральный университет, 2. Якутск

E-mail: petr korn@mail.ru

Научный руководитель: к.т.н., доцент Федотова М.A.

Муассанит - новый вид ювелирного камня [1], который существует на рынке драгоценных камней около двадцати лет. Синтетический аналог и технический продукт, аналогичный по структуре и составу — карборунд (карбид кремния) [2]. 